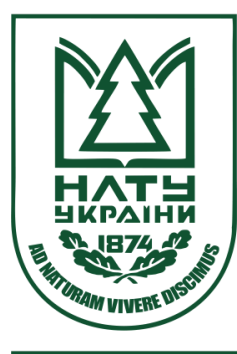

Науковий вісник НлтУ України

Scientific Bulletin of UNFU

http://nv.nltu.edu.ua

https://doi.org/10.15421/40280420

Article received $15.04 .2018 \mathrm{p}$.

Article accepted 26.04.2018 p.

I. I. Svydruk

удк 005:001.8:330.342.146

\title{
СОЦІАЛЬНО-ЕКОНОМІЧНІ АСПЕКТИ КРЕАТИВНОГО МЕНЕДЖМЕНТУ
}

Досліджено соціальні аспекти креативного менеджменту з позицій платформи соціально-економічної парадигми національної економіки та побудови соціально орієнтованого суспільства, заснованого на знаннях. Зазначено, що креативний менеджмент $\epsilon$ багатокомпонентним управлінським впливом, пов'язаним із процесами генерування і впровадження у соціально-економічний простір нових ідей, заснованих на постійно оновлюваному знанні. Показано, що завданням інституційної підтримки креативного менеджменту є сприяння розвитку високотехнологічних галузей та інтеграція національної економіки у світове науково-інноваційне співтовариство. Креативність керівника проявляється у творчому ставленні до справи, вмінні критично бачити проблему та формулювати нові задачі перед підлеглими. Доведено, що наявність антагоністичних умов вимагає поєднання жорсткості та гнучкості в управлінні, дотримання принципів "обмежувального фактора" для забезпечення конструктивного вирішення проблеми. Зазначено, що в етичному контексті завданням креативного менеджменту стає управління кумулятивним накопиченням технологічних перетворень та постійний моніторинг можливості їх позитивного, негативного (зокрема, і небажані технологічні, екологічні, інформаційно-правові ефекти) чи різновекторного впливу на безперервне оновлення вихідних умов для подальших трансформацій.

Ключові слова: національна економіка; економіка знань; креативне управління; технологічні перетворення; соціальноекономічний простір; етика креативного управління.

Вступ. Постіндустріальні тенденції експансії економіки знань відзначаються тісними інтегративними зв'язками соціальних та економічних факторів управління суспільним розвитком, їх взаємовпливом та певним взаємозаміщенням. Економічні процеси вже не можна розглядати як беззаперечну детермінанту соціального поступу, дедалі частіше спостерігаються елементи дифузної взаємодії, за якої результативна основа економіки знань включається в структуру соціальної сфери, спільно окреслюючи межі ресурсного забезпечення i розвитку (Mokyr, 2012). Під соціально-економічною організацією знань сьогодні зазвичай розуміють сукупність економічних і соціальних суспільних інституцій, що виступають регуляторами продукування, руху та кінцевого споживання знань (Yaremenko \& Nosyk, 2014). Тому дослідження соціальних аспектів креативного менеджменту $є$ надзвичайно актуальним питанням та зумовлює їх розгляд з позицій платформи соціальноекономічної парадигми національної економіки, з урахуванням стратегій економічного прориву, євроінтеграції, побудови громадянського соціально орієнтованого суспільства, заснованого на знаннях.

Аналіз наукових досліджень соціальних аспектів креативного менеджменту. Соціально-економічна інтенсифікація розвитку суспільства знань сформувала на сьогодні сучасну теорію креативного менеджменту, що охоплює проблематику цілей, завдань та методів інноваційного менеджменту, управління розвитком персоналу, теорії творчості, зокрема, науково-технічної, а та- кож використовує здобутки низки правових і соціально-економічних дисциплін. Більшість теоретичних моделей креативного менеджменту грунтуються на ендогенному походженні технологічних змін в організації, в основу ї трактування покладається результативність наукових доробок економічних суб'єктів (Zhalilo, 2009). Новітніми тенденціями $є$ врахування у виробничій функції креативного менеджменту складової інтелектуального капіталу як якісно нової змінної, величина якої прямо корелює із темпами економічного зростання (Jones \& Romer, 2010).

Дослідники у цій галузі управління сходяться на думці, що основним завданням інституційної підтримки креативного менеджменту є пришвидшена інтеграція національної економіки у світове науково-інноваційне співтовариство та сприяння розвитку високотехнологічних галузей (Barrett et al., 2014; Doroshenko, 2016). Bapто зауважити інституційну спрямованість креативного менеджменту на вирішення суспільно-пріоритетних соціально-економічних цілей розвитку. Трансформування знань у наукомісткі технології та продукти стимулює стрімке зростання продуктивності праці, зниження ii ресурсозатратності (Dzvinchuk et al., 2016). Водночас, це дає змогу вийти національній економіці на конкурентний рівень суспільного виробництва, збільшити темпи накопичення суспільних благ, осучаснити мотиваційні засади діяльності.

У сучасних економічних реаліях розвиток креативного менеджменту дослідники тісно ув'язують із таки-

Інформація про авторів:

Свидрук Ірена Ігорівна, канд. екон. наук, доцент, кафедра менеджменту. Email: irena_svidruk@ukr.net

Цитування за ДСту: Свидрук І. І. Соціально-економічні аспекти креативного менеджменту. Науковий вісник НлтУ України. Серія Економічна. 2018, т. 28, № 4. С. 108-111

Citation APA: Svydruk, I. I. (2018). Socio-Economic Aspects of Creative Management. Scientific Bulletin of UNFU, 28(4), $108-111$. https://doi.org/10.15421/40280420 
ми галузями управління, як стратегічний менеджмент, інноваційний менеджмент, управління персоналом, самоменеджмент, організаційна культура, маркетинг (Malykhina, 2012; Prodius, 2012). На нашу думку, креативний менеджмент $\epsilon$ багатокомпонентним управлінським впливом, пов'язаним із процесами генерування і впровадження у соціально-економічні процеси нових ідей, заснованих на постійно оновлюваному знанні.

Стимулювання креативного розвитку покликане забезпечити оптимальну співпрацю виконавців різної кваліфікації, з різним життєвим установками й психологічними особливостями. Мотивація творчої активності грунтується на здатності креативного працівника самостійно працювати, використовуючи власний потенціал і натхнення, що базується на високому рівні зацікавленості. Вагомим інструментом управління творчістю $\epsilon$ демократизація організації та розширення повноважень кваліфікованого персоналу, раціоналізація організації праці, наявність інтерактивного навчального середовища, позитивний соціально-психологічний клімат.

Високий рівень менеджменту креативності формує у суспільстві "спіраль знань" - концепцію розширення інтелектуальних знань і професійних навичок. Діяльність, що грунтується на цінних навичках працівника зазвичай стимулює його на подальше безперервне навчання та самовдосконалення. Важливим фактором самомотивації $є$ забезпечення автономності особистої чи групової інтелектуальної діяльності, незалежність виконавців-новаторів, оскільки психологічно вони зазвичай $\epsilon$ індивідуалістами (Khayyat, 2017). Принцип безперервності творчого процесу забезпечується постійним ускладненням наукових завдань і є в креативному менеджменті потужним мотиваційним чинником для виконання складнішої роботи через можливість задовольнити соціальну потребу спеціаліста у самовираженні. Важливим аспектом креативного менеджменту $є$ концентрація на пошуково-творчій проблемі (Svydruk, 2013). Як стимуляційний ефект до творчості працівників використовують також спеціально створені конфлікти ідей, підходів або устремлінь, пов'язані із системою цінностей виконавця. Треба розуміти, що креативне управлінське рішення ухвалюють не тільки за умов невизначеності та обмеженості ресурсів, але і суперечливості критеріїв їх ухвалення (рисунок).

\begin{tabular}{|c|c|}
\hline $\begin{array}{l}\text { Визначеність цілей } \\
\text { розвитку організації }\end{array}$ & Невизначеність зовнішніх умов \\
\hline $\begin{array}{c}\text { Стабільність процесів } \\
\text { і систем } \\
\end{array}$ & Мінливість процесів і систем \\
\hline Цілісність організації & Свобода підрозділів \\
\hline Централізація управління & Децентралізація управління \\
\hline Виконавча дисципліна & $\begin{array}{c}\text { Творчість в діяльності } \\
\text { працівників }\end{array}$ \\
\hline Науковий підхід & $\begin{array}{c}\text { Творчість у процесі розроблення } \\
\text { управлінських рішень }\end{array}$ \\
\hline
\end{tabular}

Рисунок. Дуальність умов ухвалення рішень у креативному менеджменті

Діаметрально протилежними є завдання щодо, з одного боку, максимізації прибутків та забезпечення фінансової стабільності організації, а 3 іншого - щодо мінімізації ризиків, пов'язаних з несприятливими змінами кон'юнктури. Визначальною особливістю креативного менеджменту є пряма кореляція успішності творчої діяльності із демократизацією управління, врахування творчого потенціалу і рівня професійної підготовки, створення умов для самореалізації. Отже, невід'ємною особливістю креативного менеджменту є наявність антагоністичних умов задач, що потребує поєднання жорсткості та гнучкості в управлінні, дотримання принципів "обмежувального фактора" для забезпечення конструктивного вирішення проблеми шляхом прийняття найкращої альтернативи серед потенційно можливих.

Об'єктивне існування феномену суперечливості потребує від розробників креативного рішення здатності до антиномії. Вирішення описаної дилеми досягається в креативному менеджменті завдяки застосуванню інтуїтивного способу розроблення управлінського рішення, що грунтується на спонтанності та неусвідомленості процесу. Різноманітність організаційних факторів креативного менеджменту зумовлена множинністю соціотехнічних типів організацій, складністю (що зумовлено різновекторною взаємодією аспектів творчого розвитку) та динамічністю їх взаємодії із зовнішнім середовищем, недостатністю релевантної інформації (Feist \& Barron, 2003). Інтуїція, як психологічний феномен креативного менеджменту, грунтується на особливостях мислення, інтелектуальних здібностях, досвіді, і включає два підвиди: раптове осяяння (інсайт), тобто сприйняття об'єкта під новим кутом зору, та псевдоінтуїтивне рішення, що формується на неусвідомленому використанні попередньо набутого досвіду. Зазначимо, що засади інтуїтивної моделі креативного менеджменту використовують у нейролінгвістичному програмуванні.

Близько до розглянутої суперечності знаходиться суперечність між стабільністю (стійкістю) і мінливістю (керованістю) економічної системи. Стабільність свідчить про гармонію відносин усередині і поза організацією, проте не гарантує успіху в разі зміни умов функціонування. Проблема полягає в тому, що властивість мінливості вимагає таких механізмів, які не є адекватними стабільній структурі. Водночас, без забезпечення певного рівня стабільності або стійкості, неможливо досягнути потрібної мінливості. Відомо, що у техніці суперечність між стійкістю і змінністю вирішують шляхом компромісу або перебудови системи (залежно від умов або визначених пріоритетів), при цьому сама структура стає динамічною в координатах простору i часу. Натомість в економічних системах проблема поєднання цілісності організації і свободи іiі функціональних підрозділів в умовах нестабільності і невизначеності тільки посилюється. Мистецтво керівника полягає у визначенні ступеня цієї свободи і збереженні можливості управління системою загалом. Зокрема, враховувати особливості централізації і децентралізації управління розвитком креативності персоналу, можна, виходячи 3 того, що велика за розміром компанія може перейти на дивізіональний тип відносин, запровадження плоских структур.

Поряд із описаними загальними параметрами креативного менеджменту існує специфічний - ступінь конфліктності середовища. Управлінські рішення завдяки йому набувають ознак компромісності. Зокрема, проблема мотивації стикається 3 дилемою поєднання старанності і творчості персоналу (Ulrich, 2007). Старанність і завзятість співробітників необхідні для неухильного виконання прийнятих завдань (планів, стра- 
тегій), а творчість - за пошуку ефективніших прийомів роботи. В одному працівникові рідко поєднуються виконавські і творчі здібності, і завдання менеджера знайти розумне співвідношення між творчими особистостями та сумлінними виконавцями.

Входження національної соціально-економічної системи у фазу розвитку постіндустріального суспільства висуває низку новітніх підходів до її функціонування, що грунтуються насамперед на можливості впровадження креативних ідей як першоджерела забезпечення конкурентоспроможності (Klipkova, 2015). Ієрархічно управління спонукання до творчості ускладнюється низкою чинників: збільшенням часу і "вартості" розроблення рішення, консерватизмом та інерційністю, а подекуди і блокуванням індивідуального внеску в управлінське рішення.

Розуміння своєрідності креативного менеджменту потребує врахування розумових процесів керівника у забезпеченні ефективної управлінської діяльності, мислення якого повинно мати абсолютно практично-прикладний характер. Виступаючи своєрідним арбітром креативних здобутків підлеглих, він має орієнтуватися на чіткі критерії вирішення проблем, що підлягають оцінюванню. Отож, професійною вимогою до керівника $\epsilon$ поєднання високого рівня системного мислення 3 достатнім розвитком його аналітичних здібностей. Креативність проявляється у творчому ставленні до справи, вмінні критично бачити проблему та формулювати нові задачі перед підлеглими.

3 огляду на трансформаційні виклики глобалізованого суспільства, невіддільним пріоритетом креативного менеджменту стають питання етики науково-технічної творчості та креативного розвитку економіки, що грунтуються на філософських аспектах відповідальності. Серед основних етичних принципів креативного менеджменту варто виокремити моральну відповідальність креативного працівника (відмінну від правової) за можливі негативні наслідки винаходу, що спрямовується на різні соціальні групи як у ближчій, так і у віддаленій перспективі. Етика креативного менеджменту диференціюється за ознаками спрямованості на внутрішню (стосовно замовника креативного проекту, його керівників, інших членів творчої взаємодії) та зовнішню, яка оцінює соціальні наслідки результатів креативної діяльності (зокрема, ціну помилки чи небажаних технологічних, екологічних, інформаційно-правових ефектів) для суспільства загалом. Завданням внутрішньої етики $є$ запобігання проявам наукової несумлінності, порушення правил фінансування та норм досліджень.

Спіраль розвитку знань стабілізувала чітку тенденцію до нестримного пришвидшення створення та накопичення людством креативного капіталу, що актуалізує суспільні ризики не тільки виникнення нечітко віддалених небажаних результатів науково-технічного прогресу, але й ризики незбалансованого та/чи некомпенсованого відставання певних економічних систем від глобальних тенденцій знаннєвого прогресу. Серед ключових етичних проблем сучасного креативного розвитку варто назвати можливі негативні наслідки надстрімкого розвитку біо- та нанотехнологій, атомної та постатомної енергетики, трансгенні експерименти, ризик тотального заміщення робочих місць роботизованими системами у всіх галузях економіки. Особливо чітко ці про- цеси проявляються в експансивних галузях, зокрема, у сфері комунікацій та інформаційних технологій, де життєвий цикл інноваційного продукту часом є гранично пришвидшеним, а на етапах між зародженням нового продукту та його занепадом відбувається настільки блискавично швидкий рух, що продукт подекуди навіть не встигає потрапити у зону зацікавленості своїх потенційних споживачів, витісняючись новим, більш технологічно високим продуктом.

Сучасні етичні норми креативності грунтуються на постулатах етики відповідальності щодо науково-технічної творчості, адже в глобалізаційному суспільстві наукові здобутки завжди містять певні ознаки загроз принципових змін чи навіть порушення системних основ життєдіяльності людини. Отож, в етичному контексті завданням креативного менеджменту стає управління кумулятивним накопиченням технологічних перетворень та постійний моніторинг можливості їх позитивного, негативного чи різновекторного впливу на безперервне оновлення вихідних умов для подальших трансформацій. У креативній творчості винахідник має обмежуватися самооцінкою як власних ідей, так і власних дій для майбутнього існування (у вузькому розумінні існування організації, у ширшому - існування в цивілізаційному масштабі). Тому етична відповідальність розробника має бути спрямована і на віддалені можливі результати та різні групи соціуму.

Висновки. Отже, розвиток креативного менеджменту є дієвим інструментом підвищення якості управління творчою діяльністю, а професійною вимогою до керівника є поєднання системного мислення та аналітичних здібностей. Раціональність управлінських рішень вимагає від менеджера особистої фаховості та психологічної здатності до мобілізації креативних резервів підлеглих. Створення, концентрація та раціональне впровадження знань $є$ основною запорукою конкурентоспроможності національної економіки і забезпечує стрімке соціальноекономічне зростання.

\section{Перелік використаних джерел}

Barrett, J. D., Vessey, W. B., Griffith, J. A., Mracek, D., \& Mumford, M. D. (2014). Predicting scientific creativity: the role of adversity, collaborations, and work strategies. Creativity Research Journal, 26(1), 39-52.

Doroshenko, O. S. (2016). Ekonomika znan - bazys ekonomichnoho zrostannia ta ekonomichnoho rozvytku krain [Knowledge economy is the basis of economic growth and economic development of countries]. Naukovyi visnyk Khersonskoho derzhavnoho universytetu - Scientific Herald of Kherson State University, 1(18), 27-31. [In Ukrainian].

Dzvinchuk, D. I., Liutyi, M. O., \& Petrenko, V. P. (2016). Ekonomika znan i neobkhidni zminy $\mathrm{v}$ modeliakh liderstva [Knowledge economy and necessary changes in leadership models]. Humanitarnyi visnyk Zaporizkoi derzhavnoi inzhenernoi akademii - Humanitarian Bulletin Zaporizhzhya State Engineering Academy, 64, 44-59. [In Ukrainian].

Feist, G. J., \& Barron, F. X. (2003). Predicting creativity from early to late adulthood: Intellect, potential, and personality. Journal of research in personality, 37(2), 62-88.

Jones, C. I., \& Romer, P. M. (2010). The new Kaldor facts: ideas, institutions, population, and human capital. American Economic Journal: Macroeconomics, 2(1), 224-45.

Khayyat, N. T. (2017). A Study of Telecommunication Policies and Broadband Penetration for Sweden and South Korea. Journal of Science and Engineering, 1(1), 26-34 
Klipkova, O. I. (2015). Kreatyvnist ta innovatsiinist yak osnovni skladovi novoho vektora $\mathrm{v}$ upravlinni pidpryiemstvom [Creativity and innovation as the main components of a new vector in enterprise management]. Naukovyi visnyk Mukachivskoho derzhavnoho universytetu - Scientific herald of Mukachevo State University, 2(4), 76-79. [In Ukrainian].

Malykhina, O. M. (2012). Kontseptualni osnovy upravlinnia liudskym kapitalom u protsesi rozshyrenoho vidtvorennia investytsiino-innovatsiinoho potentsialu pidpryiemstva [The conceptual foundations of human capital management in the process of expanded reproduction of the investment and innovation potential of the enterprise]. Formuvannia rynkovykh vidnosyn $v$ Ukraini - Formation of market relations in Ukraine, 10, 63-67. [In Ukrainian].

Mokyr, Joel (2012). The Gifts of Athena: Historical Origins of the Knowledge Economy. Moskva: Izd-vo Instituta Gaidara. [In Russian].

Prodius, O. I. (2012). Kreatyvnyi menedzhment yak zaporuka suchasnoho efektyvnoho upravlinnia [Creative management as a guarantee of the modern effective management]. ECONOMICS: time realities, 3-4(4-5), 67-72. [In Ukrainian].
Svydruk, I. I. (2013). Sut kreatyvnosti ta peredumovy liderstva v kreatyvnomu menedzhmenti [The essence of creativity and the prerequisites of leadership in creative management]. Scientific Bulletin of UNFU, 23(11), 372-379. [In Ukrainian].

Ulrich, D. (2007) Human Resource Champions: The Next Agenda for Adding Value and Delivering Results. Moskva: ID "Viliams". [In Russian].

Yaremenko, O. L., \& Nosyk, O. M. (2014). Sotsialno-ekonomichna orhanizatsiia znan: sutnist ta rol u formuvanni liudskoho kapitalu [Socio-economic organization of knowledge: the essence and role in the formation of human capital]. Visnyk Kharkivskoho natsionalnoho universytetu imeni $V$. N. Karazina - Bulletin of Kharkiv National University named after V. N. Karazin, 1096(87), 32-36. [In Ukrainian].

Zhalilo, Ya. (2009). Teoriia ta praktyka formuvannia efektyvnoi ekonomichnoi stratehii derzhavy [Theory and practice of forming an effective economic strategy of the state]. Kyiv: NISD. [In Ukrainian].

Львовский торгово-экономический университет, г. Львов, Украина

\section{СОЦИАЛЬНО-ЭКОНОМИЧЕСКИЕ АСПЕКТЫ КРЕАТИВНОГО МЕНЕДЖМЕНТА}

Исследованы социальные аспекты креативного менеджмента с позиций платформы социально-экономической парадигмы национальной экономики и построения социально ориентированного общества, основанного на знаниях. Отмечено, что креативный менеджмент является многокомпонентным управленческим воздействием, связанным с процессами генерации и внедрения в социально-экономическое пространство новых идей, основанных на постоянно обновляемом знании. Показано, что задачей институциональной поддержки креативного менеджмента является содействие развитию высокотехнологичных отраслей и интеграция национальной экономики в мировое научно-инновационное сообщество. Креативность руководителя проявляется в творческом отношении к делу, умении критически видеть проблему и формулировать новые задачи перед подчиненными. Доказано, что наличие антагонистических условий требует сочетания жесткости и гибкости в управлении, соблюдения принципов "ограничивающего фактора" для обеспечения конструктивного решения проблемы. Показано, что в этическом контексте задачей креативного менеджмента становится управление кумулятивным накоплением технологических преобразований и постоянный мониторинг возможности их позитивного, негативного (в том числе нежелательные технологические, экологические, информационно-правовые эффекты) или разновекторного влияния на непрерывное обновление исходных условий для дальнейших трансформаций.

Ключевые слова: национальная экономика; экономика знаний; креативное управление; технологические преобразования; социально-экономическое пространство; этика креативного управления.

\section{I. Svydruk \\ Lviv University of Trade and Economics, Lviv, Ukraine}

\section{SOCIO-ECONOMIC ASPECTS OF CREATIVE MANAGEMENT}

The introduction of the national socio-economic system into the phase of development of post-industrial society puts forward a number of new approaches to its functioning, based primarily on the possibility of introducing creative ideas as the primary source of competitiveness. The institutional orientation of creative management to address socio-priority socio-economic development goals is worth noting. The transformation of knowledge into science-intensive technologies and products stimulates the rapid growth of labour productivity, reduces its resource consumption, and allows the national economy to reach the competitive level of social production, increase the pace of accumulation of public goods, and refine the motivational principles of activity. The decisive feature of creative management is the direct correlation of the success of creative activity with the democratization of management, taking into account creative potential and the level of professional training, and creating conditions for self-realization. The stimulation of creative development is intended to provide optimal cooperation between performers of different qualifications, with different life settings and psychological peculiarities. The motivation for creative activity is based on the ability of a creative worker to work independently, using his own potential and inspiration, based on a high level of interest. The diversity of organizational factors of creative management is determined by the plurality of socio-technical types of organizations, the complexity and dynamism of their interaction with the external environment, the lack of relevant information. Understanding the uniqueness of creative management requires consideration of mental processes of the head, whose thinking should be absolutely practical and applied. Given the transformational challenges of a globalized society, the issues of ethics of scientific and technical creativity and creative economic development, which are based on the philosophical aspects of responsibility, become an inalienable priority of creative management. The ethics of creative management is differentiated on the basis of the orientation towards the internal (in relation to the customer of the creative project, the leaders, members of the creative interaction) and external, which evaluates the social consequences of the results of creative activity (including the price of errors or unwanted technological, environmental and legal effects) for society as a whole.

Keywords: national economy; knowledge economy; creative management; technological transformations; socio-economic space; ethics of creative management. 